\title{
Macro and Micro Nutrient Composition of Some Indigenous Green Leafy Vegetables in South-East Zone Nigeria
}

\section{Otitoju $\mathrm{GTO}^{1 *}$, Ene-Obong $\mathrm{HN}^{2}$ and Otitoju $\mathrm{O}^{3}$}

${ }^{1}$ Home Science, Nutrition and Dietetics, university of Nigeria, Nsukka Enugu State, Nigeria

${ }^{2}$ Department of Biochemistry, University of Calabar, Cross River State, Nigeria

${ }^{3}$ Department of Biochemistry, Federal University Wukari Taraba State, Nigeria

\begin{abstract}
There are several green leafy vegetables already implicated in possessing high nutritional values. There is still the need to add to the growing list of these beneficial plants in order to create more varieties in the food menu of the Nigeria populace. This study examined the proximate, vitamins and mineral composition of some indigenous green leafy vegetables (Psychotria $\mathrm{sp}$, Cnidoscolus aconitifolius and Telfairia occidentalis). Ten (10) kg each of the Green Leafy Vegetables (GLV) was plucked, sorted, cleaned by rinsing with deionized water and solar dried. The dried samples were pulverized and package in an air-tightpolytthene bags. The result showed that proximate composition of the GLVs showed moisture content of raw and dried samples (Psychotria sp had 62.30 and $12.87 \%$, C.aconitifolius 82.16 and $12.87 \%$ and $T$. occidentalis 86.28 and $9.82 \%$ ). Crude protein was high in raw and dried samples. It ranges from $11.75-27.32 \%$ in Psychotria sp, 4.83-24.13\% in C. aconitifolius and $5.26-35.06 \%$ for T.occidentalis. T. occidentalis had the highest ash and crude fibre (10.07 and $5.20 \%)$, followed by C.aconitifolius $(8.10$ and 4.73\%). These GLVs are good sources of pro-vitamin A, B, C and E. Psychotria sp had the highest pro-vitamin A and E (5.31-6.64 $\mathrm{mg}$ and $3.65-4.35 \mathrm{mg} / 100 \mathrm{~g}$ ) while C.aconitifolius (437.7 and $291.17 \mathrm{mg}$ ) and T.occidentalis $(420.86$ and $277.80 \mathrm{mg} / 100 \mathrm{~g})$ had the highest vitamins $\mathrm{C}$ content. These GLVs also had appreciable quantity of minerals (K, 46.43-423 mg; Na, 1.02-19.96 mg; $P$ 58.34-566.75 mg; Ca, $1.76-8.76 \mathrm{mg} ; \mathrm{Mg}, 1.20-6.02 \mathrm{mg}$ and Fe $1.77-11.80 \mathrm{mg} / 100 \mathrm{~g}$ ). This study therefore showed that Psychotria sp and Cnidoscolus aconitifolius are good sources of macro and micro nutrients.
\end{abstract}

Keywords: Macro-nutrients; Vegetables; Vitamines; Psychotria sp; Nutrition

\section{Introduction}

Micronutrients and macronutrients are comprised of vitamins and minerals which are required in small quantities to ensure normal metabolism, growth and physical well-being.

Nutrient deficiency a leading cause of anemia is a major cause of morbidity and motality among pregnant women and children in most developing nations. The problem of anemia in most rural communities in Nigeria is enormous especially among children and pregnant women. Therefore, communities tend to explore alternative and cheaper means in treating anaemic disease condition when they occur. During the documentation of indigenous food of the Igbo cultural area, Okeke et al. [1] identified Psychotria sp as a vegetable used in soup preparation and believed to have several health benefits, including the treatment of anaemia. Also Cnidoscolus aconitifolius has also been reported as a vegetable that is used in the treatment of anaemia and is popularly referred to as "hospital too far", meaning that it prevents one from visiting the hospital regularly [2].

There are many plants including green leafy vegetables that have been implicated for several health benefits and nutritional values to mankind, especially in Africa where the traditional use of many of these plants are not documented. Vegetables are those herbaceous plants whose part or parts are eaten as supporting food or main dishes and they may be aromatic, bitter or tasteless [3]. The cosumption of leafy vegetable is part of africans' cultural heritage and they play important roles in the tradition and food culture of African household. Nigeria as a country is endowed with a variety of indigenous green leafy vegetables (GLVs) and different types are consumed by the various groups for different reason. According to Mensah et al. [3], vegetables are the cheapest and most available sources of important proteins, vitamins, minerals and essential amino acids. Although, leafy vegetables are known to posses lots of minerals beneficial to human health, there is still the need to add to the growing list of these beneficial plants in order to create more varieties in the food flare of the rural populace in Nigeria. Therefore, the objective of this study is to evaluate the macro and micro nutrient potentials of some indigenous green leafy vegetables such as Cnidoscolus aconitifolius, Psychotria sp and Telfairia occidentalis as possible sources for the treatment of nutrient deficiency diseases.

\section{Material and Methods}

\section{Materials}

Sample collection and processing: Samples of Psychotria sp "Aya-azu" was collected from Ubulu-Uku, Delta State Nigeria, while Cnidoscolus aconitifolius "iyanapaja" and Telfairia occidentalis "ugu" were harvested from the vegetable gardens at Sir Louis Mbanefo Street, University of Nigeria, Nsukka (UNN). Ten (10) kg each of Psychotria sp, Cnidoscolus aconitifolius and Telfairia occidentalis leaves were plucked and sorted out by removing extraneous materials and cleaned by rinsing with deionized water. The samples were dried using solar drier $\left(32-37^{\circ} \mathrm{C}\right)$ facility at Energy Research Center, UNN. The dried samples were pulverized and packaged in air-tight-polyethene bags while the fresh samples were also freshly blended and stored in the

${ }^{*}$ Corresonding author: Otitoju Grace, Home Science, Nutrition and Dietetics, university of Nigeria, Nsukka Enugu State, Nigeria, E-mail: otitojugrace.to@gmail. com

Received July 25, 2014; Accepted October 25, 2014; Published November 04 2014

Citation: Otitoju GTO, Ene-Obong HN, Otitoju O (2014) Macro and Micro Nutrient Composition of Some Indigenous Green Leafy Vegetables in South-East Zone Nigeria. J Food Process Technol 5: 389. doi:10.4172/2157-7110.1000389

Copyright: (c) 2014 Otitoju GTO, et al. This is an open-access article distributed under the terms of the Creative Commons Attribution License, which permits unrestricted use, distribution, and reproduction in any medium, provided the original author and source are credited. 
refrigerator $\left(4-8^{\circ} \mathrm{C}\right.$ for chemical analysis in the laboratory.

\section{Proximate analysis}

Nutrient analysis: The proximate composition of the GLVs (Psychotria sp, C. aconitifolius and T. occidentalis) was determined using AOAC [4] procedures for the determination of moisture, ash, crude lipid, crude fibre and nitrogen content.

Determination of moisture content: For moisture content determination, ten fresh leaves of the sample in triplicate were weighed in Petri dishes and dried in an oven (Gallenkamp, UK) at $105^{\circ} \mathrm{C}$ for 24 hours. The dried leaves were cooled in a dessicator and weighed. The percentage loss in weight was expressed as percentage moisture content. Similar determination was carried out on two grams dry sample so as to evaluate the residual moisture content, which was used latter to convert other parameters on $100 \%$ dry weight (DW) basis.

Determination of ash content: Ash content was determined by the incineration of two grams samples in a muffle furnace (Lenton Furnaces, England) at $600^{\circ} \mathrm{C}$ for 2 hours. The percentage residue weighed was expressed as ash content.

Determination of nitrogen content: Micro-Kjeldahl method was used to determine the nitrogen content of the sample. Two grams dried powdered sample was placed into a $100 \mathrm{~cm}$ Kjeldahl digestion flask. A Kjeldahl digestion tablet and $10 \mathrm{~cm}$ of concentrated tetraoxosulphate (VI) acid were added and the sample digested gently until frothing stopped. The mixture was boiled until the digest become clear. The content was filtered into a $100 \mathrm{~cm}$ volumetric flask and made up to 100 $\mathrm{cm}$ with distilled water. $10 \mathrm{~cm}$ of the aliquot solution and $20 \mathrm{~cm}$ of $45 \%$ sodium hydroxide solution were put into a distillation flask and steam distilled. The ammonia liberated was collected over $50 \mathrm{~cm} 20 \%$ boric acid mixed indicator solution, cooled and titrated with standard $0.01 \mathrm{M}$ $\mathrm{HCl}$ solution. Blank determination was carried in similar manner.

Estimation of crude protein and available carbohydrate: Crude protein was estimated by multiplying the sample percentage nitrogen content by a factor 6.25 . Available carbohydrate was calculated by difference by subtracting total sum of crude protein, crude lipid, crude fibre and ash from $100 \%$ DW sample [5].

Determination of crude lipid content: $2 \mathrm{~g}$ of dried samples were weighed into porous thimble and its mouth plugged with cotton. The thimble was placed in an extraction chamber, which was suspended above weighed into receiving flask containing petroleum ether (B.P 40$60^{\circ} \mathrm{C}$ ) and below a condenser. The flask was heated on heating mantle for eight hours to extract the crude lipid. After the extraction, the thimble was removed from the Soxhlet and the apparatus reassembled and heated over water bath for the solvent recovery. The flask containing the crude lipid was disconnected, cleaned with dry cloth, oven dried at $100^{\circ} \mathrm{C}$ for 30 minutes, cooled in a dessicator and weighed. The difference in weight is expressed as percentage crude lipid content.

Determination of Crude Fibre Content: Crude fibre was estimated by acid-base digestion with $1.25 \% \mathrm{H}$ SO (w/v) and $1.25 \%$ $\mathrm{NaOH}(\mathrm{w} / \mathrm{v})$ solutions residue after crude lipid extraction was put into a $60 \mathrm{~cm}^{3}$ beaker and $200 \mathrm{~cm}^{3}$ of boiling $1.25 \% \mathrm{H} \mathrm{SO}$ added. The content was boiled for 30 minutes, cooled, filtered through a filter paper and residue washed with three $50 \mathrm{~cm}^{3}$ portions of boiling water. The drained residue was returned to the original beaker and $200 \mathrm{~cm}^{3}$ of boiling $1.25 \% \mathrm{NaOH}$ added. The content was boiled for 30 minutes, filtered, washed as above, residue drained

\section{Statistical analysis}

The data are expressed as mean \pm SEM. Statistical analysis was carried out by one-way analysis of variance (ANOVA). Difference were considered to be statistically significant when $\mathrm{p}<0.05$.

\section{Results}

Table 1 shows the proximate composition result of the green leafy vegetables. The moisture content of raw samples showed that Psychotria sp had $62.30 \%$, C. aconitifolius $82.16 \%$ and T. occidentalis had $86.28 \%$. Crude protein result showed that raw Psychotria sp, C. aconitifolius and T. occidentalis had $11.75 \%, 4.83 \%$ and $5.26 \%$ respectively. Fat content in Psychotria sp was $3.68 \%$, C. aconitifolius $1.61 \%$ and T. occidentalis $1.25 \%$. Carbohydrate results in the three raw samples were $17.54 \%$, $8.52 \%$ and $4.72 \%$ respectively. Crude fiber content of raw samples showed that Psychotria sp had $1.46 \%$, C. aconitifolius had $0.95 \%$ and T. occidentalis had $0.78 \%$. Ash content in Psychotria sp was $3.04 \%$ while $C$. aconitifolius and T. occidentalis had $1.62 \%$ and $1.51 \%$ respectively. The result of solar-dried samples showed that Psychotria sp, C. aconitifolius and T. occidentalis had $12.87 \%, 12.73 \%$ and $9.82 \%$ moisture content respectively. Protein value for Psychotria sp was $27.32 \%$, while that of $C$. aconitifolius and T. occidentalis were $24.13 \%$ and $35.06 \%$ respectively. Fat result showed that Psychotria sp had $8.55 \%$, C. aconitifolius $8.05 \%$ and T. occidentalis had $8.36 \%$. Carbohydrate content of raw Psychotria sp, C. aconitifolius and T. occidentalis were $40.80 \%, 42.69 \%$ and $31.49 \%$ respectively, while the ash contents were $7.06 \%, 8.10 \%$ and $10.07 \%$ respectively.

Vitamin composition of fresh and dried samples of Psychotria $s p, C$. aconitifolius and T. occidentalis is presented in Table 2. In the fresh samples, pro-vitamin A concentrations for Psychotria sp, C. aconitifolius and T. occidentalis were $5.31,0.66$ and $1.23 \mathrm{mg} / 100 \mathrm{~g}$ respectively. Vitamin $B_{2}$ content in Psychotria $s p$ was $0.04 \mathrm{mg} / 100 \mathrm{~g}$, C. aconitifolius had $0.06 \mathrm{mg} / 100 \mathrm{~g}$ and T. occidentalis $0.08 \mathrm{mg} / 100 \mathrm{~g}$. However, vitamin $\mathrm{C}$ and $\mathrm{E}$ concentrations in raw Psychotria sp were 30.50 and $3.65 \mathrm{mg} / 100 \mathrm{~g}$ respectively, while in Cnidoscolus they were 437.7 and $0.38 \mathrm{mg} / 100 \mathrm{~g}$ respectively. In fresh Telfaria samples, vitamin $\mathrm{C}$ and $\mathrm{E}$ concentrations were 420.86 and $0.56 \mathrm{mg} / 100 \mathrm{~g}$ respectively. However, the result of the solar-dried samples showed that Psychotria had 6.64 and $0.14 \mathrm{mg} / 100 \mathrm{~g}$ pro-vitamin $A$ and vitamin $B_{2}$ respectively. Also, vitamin $\mathrm{C}$ and $\mathrm{E}$ content of dried Psychotria 20.00 and 4.35 $\mathrm{mg} / 100 \mathrm{~g}$ respectively. The vitamin content of Cnidoscolus was as follow: 0.18 provitamin $\mathrm{A}, 0.60 \mathrm{~B}_{2}, 291.17$ vitamin $\mathrm{C}$ and $0.47 \mathrm{mg} / 100$ g vitamin E. Solar-dried Telfaria samples had 0.85 provitamin A, 0.80 vitamin $B_{2}, 277.80$ Vitamin $C$ and $0.74 \mathrm{mg} / 100 \mathrm{~g}$ Vitamin E. Generally, vitamins A, B, and E contents of Psychotria sp and C. aconitifolius were higher than the T. occidentalis. Similarly, the solar dried samples had the highest vitamin content when compared with the raw samples. In addition, the Psychotria sp tends to show some vitamin advantage (provitamin $\mathrm{A}$ and vitamin $\mathrm{E}$ ) over the other two samples.

Mineral composition of Psychotria sp, C. aconitifolius and T. occidentalis is presented in Table 3. Fresh samples results showed that potassium (K) concentration for Psychotria sp, C. aconitifolius and T. occidentalis were $129.44,85.06$ and $46.43 \mathrm{mg} / 100 \mathrm{~g}$ respectively. Sodium (Na) content of Psychotria $s p$ was $4.79 \mathrm{mg} / 100 \mathrm{~g}, 3.99 \mathrm{mg} / 100 \mathrm{~g}$ for $C$. aconitifolius and $1.53 \mathrm{mg} / 100 \mathrm{~g}$ for T. occidentalis. Phosphorus (P) and Zinc (Zn) concentrations in fresh Psychotria sp were 243.70 and 3.69 $\mathrm{mg} / 100 \mathrm{~g}$, respectively while in C. aconitifolius the concentrations were 80.59 and $1.83 \mathrm{mg} / 100 \mathrm{~g}$. Fresh samples of T. occidentalis had 58.34 and $1.02 \mathrm{mg} / 100 \mathrm{~g}$ of $\mathrm{P}$ and $\mathrm{Zn}$, respectively. The results of the solar-dried samples showed that Psychotria sp had $301.01 \mathrm{mg} / 100 \mathrm{~g}$ potassium, while C. aconitifolius had $425.03 \mathrm{mg} / 100 \mathrm{~g}$ and T. occidentalis had $309.50 \mathrm{mg} / 100 \mathrm{~g}$ potassium. $\mathrm{Na}$ and $\mathrm{P}$ concentrations in Psychotria $s p$ were 11.03 and $566.75 \mathrm{mg} / 100 \mathrm{~g}$, while C. aconitifolius had 19.96 
Citation: Otitoju GTO, Ene-Obong HN, Otitoju O (2014) Macro and Micro Nutrient Composition of Some Indigenous Green Leafy Vegetables in SouthEast Zone Nigeria. J Food Process Technol 5: 389. doi:10.4172/2157-7110.1000389

Page 3 of 6

\begin{tabular}{|c|c|c|c|c|c|c|c|}
\hline Vegetables & & Moisture & Protein & Fat & Carbohydrate & $\begin{array}{l}\text { Crude } \\
\text { Fiber }\end{array}$ & Ash \\
\hline \multirow{2}{*}{ Psychotria sp } & Fresh & $62.30 \pm 2.53$ & $11.75 \pm 2.00$ & $3.68 \pm 0.23$ & $17.54 \pm 1.54$ & $1.46 \pm 0.04$ & $3.04 \pm 0.52$ \\
\hline & Dry & $12.87 \pm 1.24$ & $27.32 \pm 0.24$ & $8.55 \pm 0.26$ & $40.80 \pm 0.07$ & $3.40 \pm 0.22$ & $7.06 \pm 0.13$ \\
\hline \multirow{2}{*}{ C. aconitifolius } & Fresh & $82.16 \pm 1.87$ & $4.83 \pm 1.56$ & $1.61 \pm 0.06$ & $8.52 \pm 1.33$ & $0.95 \pm 0.04$ & $1.62 \pm 0.23$ \\
\hline & Dry & $12.73 \pm 0.76$ & $24.13 \pm 0.26$ & $8.05 \pm 0.04$ & $42.69 \pm 0.30$ & $4.73 \pm 0.09$ & $8.10 \pm 0.08$ \\
\hline \multirow{2}{*}{ T. occidentalis } & Fresh & $86.28 \pm 3.22$ & $5.26 \pm 0.45$ & $1.25 \pm 0.06$ & $4.72 \pm 0.53$ & $0.78 \pm 0.11$ & $1.51 \pm 0.09$ \\
\hline & Dry & $9.82 \pm 0.27$ & $35.06 \pm 0.09$ & $8.36 \pm 009$ & $31.49 \pm 0.05$ & $5.20 \pm 0.04$ & $10.07 \pm 0.07$ \\
\hline
\end{tabular}

Mean $\pm \operatorname{SD}(n=3)$

Table 1: Proximate compositions (\%) of Psychotria sp, C. aconitifolius and T. occidentalis samples

\begin{tabular}{|c|c|c|c|}
\hline $\begin{array}{c}\text { Green leafy } \\
\text { Vegetables }\end{array}$ & $\begin{array}{c}\text { Pro-Vitamin.A } \\
\text { (mg/100 g) }\end{array}$ & $\begin{array}{c}\text { Vitamin B } \\
\text { (mg/100 g) }\end{array}$ & $\begin{array}{c}\text { Vitamin E } \\
\text { (mg/100 g) }\end{array}$ \\
\hline Psychotria sp (Fresh) & $5.31 \pm 0.52$ & $0.04 \pm 0.01$ & $3.65 \pm 0.32$ \\
\hline Psychotria sp (dried) & $6.64 \pm 1.78$ & $0.14 \pm 0.02$ & $30.5 \pm 2.56$ \\
\hline C. aconitifolius (Fresh) & $0.66 \pm 0.07$ & $0.063 \pm 0.02$ & $20.00 \pm 3.26$ \\
\hline C. aconitifolius (dried) & $0.18 \pm 0.02$ & $0.60 \pm 0.02$ & $437.7 \pm 21.56$ \\
\hline${ }^{*}$ T. occidentals (Fresh) & $1.23 \pm 0.07$ & $0.082 \pm 0.01$ & $291.17 \pm 5.79$ \\
\hline${ }^{*}$ T. occidentalis (dried) & $0.85 \pm 0.02$ & $0.80 \pm 0.04$ & $420.86 \pm 32.77$ \\
\hline
\end{tabular}

${ }^{*}$ Indicates the control Mean $\pm S D(n=2)$

Table 2: Vitamins content of Psychotria sp, C. aconitifolius and T. occidentalis samples

\begin{tabular}{|c|c|c|c|c|c|c|c|c|c|c|}
\hline \multicolumn{2}{|c|}{ Vegetables } & $\mathbf{K}$ & $\mathrm{Na}$ & $\mathrm{Zn}$ & $\mathrm{Ca}$ & Mg & $\mathrm{Cu}$ & $\mathrm{Fe}$ & Mn & \\
\hline & \multicolumn{10}{|c|}{$(\mathrm{mg} / 100 \mathrm{~g})$} \\
\hline \multirow{2}{*}{ Psychotria sp } & Fresh & $129.44 \pm 11.03$ & $4.79 \pm 0.67$ & $243.70 \pm 31.53$ & $3.69 \pm 0.23$ & 3.090 .67 & $2.39 \pm 0.04$ & $0.29 \pm 0.04$ & $4.34 \pm 0.35$ & 1.430 .03 \\
\hline & Dried & $301.01 \pm 21.69$ & $11.03 \pm 2.11$ & $566.75 \pm 22.39$ & $8.59 \pm 1.22$ & $7.19 \pm 1.44$ & $5.56 \pm 0.33$ & $0.67 \pm 0.02$ & $10.08 \pm 1.60$ & $3.34 \pm 0.56$ \\
\hline \multirow{2}{*}{ C. aconitifolius } & Fresh & $85.06 \pm 5.39$ & $3.99 \pm 0.55$ & $80.59 \pm 2.73$ & $1.83 \pm 0.09$ & $1.76 \pm 0.23$ & $1.20 \pm 0.05$ & $0.10 \pm 0.00$ & $1.72 \pm 0.03$ & $0.78 \pm 0.03$ \\
\hline & Dried & $425.03 \pm 17.55$ & $19.96 \pm 2.79$ & $402.96 \pm 5.96$ & $9.16 \pm 1.24$ & $8.79 \pm 1.32$ & $6.02 \pm 0.62$ & $0.51 \pm 0.02$ & $8.62 \pm 0.55$ & $3.91 \pm 0.06$ \\
\hline \multirow{2}{*}{ T. occidentalis } & Fresh & $46.43 \pm 3.85$ & $1.53 \pm 0.32$ & $58.34 \pm 1.65$ & $1.02 \pm 0.01$ & $0.96 \pm 0.04$ & $0.74 \pm 0.15$ & $0.14 \pm 0.01$ & $1.77 \pm 0.23$ & $0.56 \pm 0.01$ \\
\hline & Dried & $309.50 \pm 27.90$ & $10.29 \pm 1.54$ & $389.06 \pm 1.26$ & $6.81 \pm 054$ & $6.40 \pm 1.12$ & $4.91 \pm 0.44$ & $0.96 \pm 0.02$ & $11.80 \pm 1.15$ & $3.71 \pm 0.32$ \\
\hline
\end{tabular}

*Indicates the control Mean $\pm S D(n=2)$

Mean $\pm S D(n=3)$

Table 3: Mineral contents of Psychotria sp, C. aconitifolius and T. occidentalis samples

and $402.96 \mathrm{mg} / 100 \mathrm{~g}$ respectively. In T. occidentalis, $\mathrm{Na}$ and $\mathrm{P}$ were 10.29 and $389.06 \mathrm{mg} / 100 \mathrm{~g}$, respectively. $\mathrm{Zn}$ and $\mathrm{Ca}$ concentration in Psychotria sp were 8.59 and $7.19 \mathrm{mg} / 100 \mathrm{~g}$, C. aconitifolius had 9.16 and $8.79 \mathrm{mg} / 100 \mathrm{~g}$ while $T$. occidentalis had 6.81 and $6.40 \mathrm{mg} / 100 \mathrm{~g}$ respectively. $\mathrm{Mg}$ and $\mathrm{Cu}$ concentrations in Psychotria sp were 5.56 and $0.67 \mathrm{mg} / 100 \mathrm{~g}$, C. aconitifolius 6.02 and $0.51 \mathrm{mg} / 100 \mathrm{~g}$ and T. occidentalis had 4.91 and $0.96 \mathrm{mg} / 100 \mathrm{~g}$. Iron $(\mathrm{Fe})$ and $\mathrm{Mn}$ concentrations in Psychotria sp were 10.08 and $3.34 \mathrm{mg} / 100 \mathrm{~g}$, C. aconitifolius had 8.62 and $3.91 \mathrm{mg} / 100 \mathrm{~g}$. T. occidentalis had 11.80 and $3.71 \mathrm{mg} / 100 \mathrm{~g} \mathrm{Fe}$ and Mn respectively.

\section{Discussion}

Psychotria sp and C. aconitifolius leaves are among the vegetables sparingly consumed in the south-eastern Nigeria. The young leaves are cooked as green vegetables while the shrubs are used as boundary divider. The proximate composition of Psychotria sp, C. aconitifolius and T. occidentalis shows that they have high moisture (water) contents like most other vegetables. Moisture content is a widely used parameter in the processing and testing of food. It is an index of water activity of many foods. The observed high values implies that these vegetables may have short shelf life because microorganisms that cause spoilage thrive in foods having high moisture content and also is an indicative of low total solids [6,7]. The high moisture content is consistent with the report of Ekumankama [8] who also observed a high moisture value for vegetables like Pterocarpus soyauxii (Oha) (83.75\%), Pterocarpus santalinoides (Nturukpa) (80.75\%) and Gnetum africanum (Okazi). Similarly, the high moisture content provides for greater activity of water soluble enzymes and co-enzymes needed for metabolic activities of these leafy vegetables [9]. Fruits and vegetables contain large quantities of water in proportion to their weight. When these foods are eaten, the water can be absorbed by the body [10].

The carbohydrate content of Psychotria sp and C. aconitifolius were about $73 \%$ and $44.6 \%$ (fresh weight) respectively higher than T. occidentalis. According to Emebu and Anyika [11], carbohydrates are pivotal nutrients required for adequate diet. Psychotria sp and C. aconitifolius like most vegetables contains high level carbohydrate but lower than that of other vegetables such as Amaranthus hybridus (52.18\%) [12]. The fat content of Psychotria sp was higher than Cnidocolius and Telfaria. This may suggest that these latter vegetable may not be a high fat content vegetable. It could therefore be used by individuals on weight reduction. However, Psychotria sp may not fattened because of its high level of crude fiber.

Psychotria $s p$ is also a good source of vegetable protein having a protein content of $11.75 \%$. This value was higher than that $(3.3 \%)$ recorded by the USDA Nutrient Database for Standard Reference [13]. Its protein content makes it suitable for consumption, as a necessity for body development. The protein value of Psychotria sp as observed in this study confers on it the advantage as a rich source of vegetable protein over some vegetables such as raw cocoyam leaf (3.4\%), cooked cocoyam 
leaf (2.1\%), Amaranthus (6.1\%) and Moringa oleifera (4.2\%) as reported by Adepoju. Chima and Igyor [14] also recorded lower protein values for "Oha" (2.0\%) and 'Okazi' (1.5\%). Incorporating Psychotria sp in the diet can furnish it with sizeable amounts of protein which provides enormous benefits such as maintenance of fluid balance, formation of hormones and enzymes, contribution to immune function, to mention but a few. The fiber content of Psychotria sp (1.46\%) was found to be lower than that of some other Nigerian vegetables such as "Oha" (Pterocarpus soyauxii) 13.1\%, "Nturukpa" (Pterocarpus santalinoides) 10.55\%, "Okazi" (Gnetum africanum) 24.6\% (Ekumankama, 2008) and pigweed (Amaranthus hybridus) $8.61 \%$ but higher than that of Telferia occidentalis $(0.78 \%)$ and Piper guineense (2.9\%). Fibre cleanses the digestive tract, by removing potential carcinogens from the body and prevents the absorption of excess cholesterol. Fibre also adds bulk to the food and prevents the intake of excess starchy food and may therefore guard against metabolic conditions such as hypercholesterolemia and diabetes mellitus. Fiber binds to cancer-causing chemicals, keeping them away from the cells lining the colon, providing yet another line of protection from colon cancer [15]. Psychotria sp may also be recognized as an excellent source of fiber, which is an important consideration for people who suffer from elevated cholesterol levels and in helping to cleanse the colon [16]. According to Gates [17], a number of studies have indicated that components of plants such as dietary fiber have beneficial effects in lowering blood cholesterol levels aside from the decreased intake of saturated fat and cholesterol that occurs with high intakes of plant foods. Leafy vegetables serve as supplements for food and also have the potential to improve the health status of its users as a result of the presence of various compounds vital for good health. Their fiber content provides bulk in the diet and this helps to reduce the intake of starchy foods, enhances gastrointestinal function, prevents constipation and may thus reduce the incidence of metabolic diseases like maturity onset diabetes mellitus and hypercholesterolemia. Fibre cleanses the digestive tract, by removing potential carcinogens from the body and prevents the absorption of excess cholesterol. High fiber content and antibacterial activities of this plant have been reported [18]. Fibre also adds bulk to the food and prevents the intake of excess starchy food and may therefore guard against metabolic conditions such as hypercholesterolemia and diabetes mellitus [19]. Current information on the nutritive and medicinal value of many lesser known vegetables is scanty. In most cases, this knowledge is not well documented and disseminated. Ash content which is an index of mineral contents in biota was also high (3.04\%) in Psychotria leaf as compared to the values in the leaves of Telfaria (1.51\%). The values of Ash content obtained in this work was generally low compared with earlier work reported for other vegetables like Talinum triangulare (20.05\% DW) [20], Ipomea batatas $(11.10 \%)$, Vernonia colorate $(15.86 \%)$ and Moringa oleifera (15.09\% DW) [21], Ocimum gratissium (18.00\% DW) and Hibiscus esculentus (8.00\% D W) [22]. Ukam [23] stated that the lower the ash content, the higher the nutrient quality. Psychotria sp therefore could be recommended for the preparation of different Nigerian dishes due to its nutritional potentials.

Psychotria sp and C. aconitifolius were high in potassium, Iron, $\mathrm{Mg}, \mathrm{Na}, \mathrm{P}, \mathrm{Zn}$ and $\mathrm{Ca}$. Ekumankama and Mensah et al. reported lower calcium levels for other vegetables such as Oha, Nturukpa, Okazi, $A$. cruentus, Celosia sp. And V. amygdalina. Furthermore, based on the findings on the mineral contents from this study, a significant percent of the daily calcium requirement for the average Nigerian can be met through judicious use of Psychotria sp and C. aconitifolius for meal preparation. Calcium is a major factor sustaining strong bones and plays a part in muscle contraction and relaxation, blood clotting, synaptic transmission and absorption of vitamin B12. The relatively high content of calcium $(3.09 \mathrm{mg} / 100 \mathrm{~g})$ in Psychotria sp suggests that it may be of therapeutic value in hypocalcaemic state like osteoporosis. Iron level of Psychotria $s p$ was also high $(4.34 \mathrm{mg} / 100 \mathrm{~g})$ than the FAO/ WHO [24] recommended dietary allowance for males $(1.37 \mathrm{mg} / \mathrm{day})$ and females $(2.94 \mathrm{mg} /$ day). Iron has been reported as an essential trace metal and plays numerous biochemical roles in the body, including oxygen binding in haemoglobin and acting as an important catalytic center in many enzymes, for example, the cytochrome system [25]. It is estimated that 2 billion of the world's population (largely in developing countries) have marked iron deficiency anaemia [26]. This in turn limits work performance and leads to impaired performance in mental and motor tests in children [27]. In infants, children and adolescents, iron is also required for growth of the tissues and organs and for the expanding red blood cell mass.

The use of Psychotria sp in the diet can furnish the diet with iron sufficient enough to meet the daily requirement for the nutrient. Green leafy vegetables also contain iron needed in haemoglobin formation and hence recommended for anaemic convalescence. Psychotria sp has relatively high iron $(\mathrm{Fe})$ contents and may be recommended for iron deficiency anaemia. Various minerals such as $\mathrm{Zn}, \mathrm{Mg}$ and $\mathrm{Mn}$ are also co-enzymes in certain biochemical reactions in the body which underscores the importance of leafy vegetables in metabolic reactions. The zinc content of Psychotria sp was also found to be lower than that of other vegetables like "Afang" $(5.20 \mathrm{mg} / 100 \mathrm{~g})$, "Editan" (7.40 mg/100 g) and "Atama" (12.00 mg/100 g). FAO/ WHO [28] reported that zinc is an essential component of a large number $(>300)$ of enzymes participating in the synthesis and degradation of carbohydrates, lipids, proteins, and nucleic acids as well as in the metabolism of other micronutrients. Zinc stabilizes the molecular structure of cellular components and membranes and contributes in this way to the maintenance of cell and organ integrity. Furthermore, zinc has an essential role in polynucleotide transcription and thus in the process of genetic expression. Its involvement in such fundamental activities probably accounts for the essentiality of zinc for all life forms. Zinc plays a central role in the immune system, affecting a number of aspects of cellular and humoral immunity [29]. Magnesium is widely distributed in vegetables, most green vegetables, legume seeds, peas, beans and nuts are rich in magnesium [30]. From the results of this study, it is clear that Psychotria sp and Cnidocolius, though lesser known vegetables, have enormous nutritional potentials and thus can favourably be used as alternative good sources of vegetable.

Generally, vegetables are rich in vitamins, minerals, trace elements, dietary fibre and proteins [31-34]. The result of this study showed that Psychotria and Cnidoscolus are rich sources of pro-vitamin A, vitamin $\mathrm{C}$ and vitamin $\mathrm{E}$. This finding is in agreement with the result of RoseIbarra and Molina-Cruz who reported that Cnidoscolus (Chaya) is a rich source of vitamin $\mathrm{C}, \beta$-carotene and the B-vitamins. Psychotria sp had the highest level of pro-vitamin $\mathrm{A}$, a vitamin that protect the body cells from the damaging effects of free radicals, they act as good source of vitamin A and Enhance the functioning of the immune system. Similarly, pro-vitamin A also Help the reproductive system to function properly [35,36]. The high level of pro-vitamin A in Psychotria sp is a good quality of the Lesser Known Vegetable (LKV) that could be promoted to consumers for its health benefits. Previous studies have reported that leafy vegetables have great potential for the alleviation of nutritional deficiencies in the populations of developing countries, as it is rich in essential amino acids and vitamin [37-39]. Psychotria $s p$ possessed the lowest concentrations of vitamin $B_{2}$ and vitamin $C$ while the highest values of both vitamins were present in C. aconitifolius and 
Citation: Otitoju GTO, Ene-Obong HN, Otitoju O (2014) Macro and Micro Nutrient Composition of Some Indigenous Green Leafy Vegetables in SouthEast Zone Nigeria. J Food Process Technol 5: 389. doi:10.4172/2157-7110.1000389

T. occidentalis respectively. Ascorbic acid (vitamin C) is an antioxidant which helps to protect the body against cancer and other degenerative diseases such as arthritis and type II diabetes mellitus [40,41]. It also strengthens the immune system. In fact, green vegetables with high ascorbic acid content, such as Cnidoscolus may enhance the absorption of non-heme iron. The antioxidant activity of Cnidoscolus may be due to its chemical constituents, such as tannins, phenolics, flavonoids, saponins, and vitamins A and C $[42,43]$. Additionally, ascorbic acid may potentially act as an anticancer agent [44]. Vitamin E contents of the samples revealed that Psychotria sp has the highest while the lowest was $C$. acconitifolius. Vitamin $E$ is an integral part of cellular membranes whose main role is to defend the cell against oxidation. Within cells and organelles (e.g. mitochondria), it is the first line of defense against lipid peroxidation. This vitamin also plays a very important function in lending Red Blood Cells (RBC) flexibility as they make their way through the arterial network [45,46]. Emeka and Onyechi [47] reported that lipid peroxidation significantly reduced in the animals fed with Telfaria diet because of the presence of high concentration of vitamins present in this vegetable. This result confirms the antioxidant effects of Telfairia extracts reported by Nwanna and Oboh [48]. Anti oxidant effects of vegetables such as Telfairia have been attributed to the presence of phenolic compounds such as flavonoids, polyphenols as well as vitamins [49].

In conclusion, the findings of this research work showed that the Lesser Known Vegetables (LKVs) Psychotria sp and Cnidoscolus aconitifolius are good sources of macro and micro nutrients in respect to high protein content, vitamin $\mathrm{C}$, vitamin $\mathrm{B}$, vitamin $\mathrm{A}$, vitamin $\mathrm{E}$, Potassium, Zinc, Calcium, and Iron. They could be useful as possible sources for combating mineral or macronutrient deficiencies.

\section{References}

1. Okeke EC, Eneobong HN, Uzuegbunam AO, Ozioko AO, Kuhnlein H (2008) Igbo Traditional Food System: Documentation, Uses and Research Needs. Pak J Nutr 7: 365-376.

2. Ross Ibarra J, \& Molina-Cruz A (2002) The ethnobotany of chaya (Cnidoscolus aconitifolius ssp. aconitifolius Breckon): A nutritious Maya vegetable. Economic Botany 56: 350-365.

3. Mensah JK, Okoli RI, Ohaju-Obodo JO, Eifediyi K (2008) Phytochemical, nutritional and medical properties of some leafy vegetables consumed by Edo people of Nigeria. African Journal of Biotechnology 7: 2304-2309.

4. Association of Official Analytical Chemists (AOAC 2000) Folic acid. In Official Methods of analysis, 16th ed. Washington, DC: Association of Official Analytical Chemists.

5. AOAC (1990) Official methods of analysis of the Association of Official Analytical Chemists, $\left(15^{\text {th }}\right.$ Edition). Association of Official Analytical Chemists, Arlington VA.

6. Pearson D (1976) Chemical analysis of food, (7thedn), churchill, London.

7. Adepoju OT, Onasanya LO, Udoh CH (2006) Comparative studies of nutrient composition of cocoyam (Colocassia esculenta) leaf with some green leafy vegetables. Nig J Nutr Sci 27: 40-43.

8. Ekumankama 10 (2008) Nutrient composition of indigenous vegetables (Pterocarpus soyanxii, Pterocarpus santalinoides and Gnetum africanum). Nig J Nutr Sci 29: 195-200.

9. Iheanacho KME, Udebuani AC (2009) Nutritional Composition of Some Leafy Vegetables Consumed in Imo State, Nigeria. J Appl Sci Environ Manage September 13: 35-38.

10. Sandra B, Kim H (1994) Extension Associate for ENRI.Information taken from Bowes \& Church's Food Values.

11. Emebu PK, Anyika JU (2011) Proximate and Mineral Composition of Kale (Brassica oleracea) Grown in Delta State, Nigeria. Pakistan Journal of Nutrition 10: 190-194.
12. Akubugwo IE, Obasi NA, Chinyere GC, Ugbogu AE (2007) Nutritional and chemical value of Amaranthus hybridus L. leaves from Nigeria. Afr J Biotechnol 6: 2833-2839.

13. Hall R (1998) Kale, Brassica oleraceae (Acephala Group). USDA Database for Standard Reference. Nutrition guide.

14. Chima CE, Igyor MA (2007) Micronutrient and antinutritional contents of selected tropical vegetables grown in South East, Nigeria. Nig Food J 25: 111116.

15. Ensminger AH, Esminger MKJ (1996) Food for Health: A Nutrition Encyclopedia Pegus Press, Clovis, California.

16. Zhao HL, Grossman HB, Hernandez LM, Dinney CP, Wu X (2007) Dietary isothiocyanates, GSTM1, GSTT1, NAT2 polymorphisms and bladder cancer risk. Int J Cancer 120: 2208-2213.

17. Gates JC (1984) Basic Foods. Holts, Rinehart and Winston, Canada 171: 186 192.

18. Oyagbemi AA, Odetola AA, Azeez OI (2008) Ameliorative effects of Cnidoscolus aconitifolius on anaemia and osmotic fragility induced by protein energy malnutrition. Journal of biotech 7: 1721-1726.

19. Barry KA, Wojcicki BJ, Bauer LL, Middelbos IS, Vester Boler BM, et al. (2011) Adaptation of healthy adult cats to select dietary fibers in vivo affects gas and short-chain fatty acid production from fiber fermentation in vitro. J Anim Sci 89 3163-3169.

20. Ladan MJ, Bilbils LS, Lawal M (1996) Nutrient composition of some green leafy vegetable consumed in Sokoto. Nig J Basic Appl Sci 5: 39-44.

21. Antia BS, Akpan EJ, Okon PA, Umoren IU (2006) Nutritive and antinutritive evaluation of sweet potatoes (Ipomoea batatas) leaves. Pak J Nutr 5: 166-168.

22. Akindahunsi AA, Salawu SO (2005) Phytochemical screening, nutrient and anti -nutrient composition of selected tropical green leafy vegetables. Afr J Biotechnol 4: 497-501.

23. Ukam NU (2008) The potentials of some lesser known vegetables. Nig J Nutr Sci 29: 299-305

24. FAO (1988) United Nations Food and Agricultural Organization: Traditiona food plants. Food and Agricultural Organization (FAO) Food Nutrition. FAO, Rome.

25. Geissler CA, Powers HJ (2005) Human Nutrition. (11 th Edition). Elsevier Churchill Livingstone.

26. World Health Organisation (1997) Monograph on selected medicinal plants. Geneva: World Health Organisation.

27. Lockeett CT, Calvert CC, Grivetti LE (2000) Energy and micronutrient composition of dietary and Medicinal wild plants consumed during drought: Study of Rural Fulani, Northeastern Nigeria. Int J Food Sci Nutr 51: 195-208.

28. FAO/WHO (2001) Human vitamin and mineral requirements. Report of a Joint FAO/WHO Expert consultation, Bangkok, Thailand. Food and Nutrition Division, FAO Rome.

29. Shankar AH, Prasad AS (1998) Zinc and immune function: The biological basis of altered resistance to infection. Am J Clin Nutr 68: 447S-463S.

30. Ariel RV, George AM, Gabriel OS, Carlos HC (2009) Nutritional Quality of Fruits and Vegetables. In Postharvest Handling: A Systems Approach, Second Edition Edited by Wojciech J. Florkowski, Robert L. Shewfelt, Bernhard Brueckner and Stanley E. Prussia. Elsevier Inc. Academic Press.

31. Humphrey CM, MS Clegg, CL Keen and LE Grivetti (1993) Food diversity and drought survival: The Hausa example. Int J Food Sci and Nutrit 44: 1-16.

32. Mathenge $L$ (1997) Nutrition value and utilization of indigenous vegetables in Kenya. Traditional African Vegetables: Proceedings of the IPGRI International workshop on Genetic Resources of Traditional Vegetables in Africa. Conservation and Use. ICRAF-HQ, Nairobi. Institute of Plant Genetic and Crop Plant Research, Rome.

33. Maundu PM (1997) The status of traditional vegetable utilisation in Kenya Traditional African Vegetables. Proceedings of the IPGRI International workshop on Genetic Resources of Traditional Vegetables in Africa. Conservation and Use. ICRAF-HQ, Nairobi. Institute of Plant Genetic and Crop Plant Research, Rome.

34. Okafor JC (1981) Horticulturally promising indigenous wild plant species of the Nigerian forest zone Acts. Horticulture 123: 165-177. 
Citation: Otitoju GTO, Ene-Obong HN, Otitoju O (2014) Macro and Micro Nutrient Composition of Some Indigenous Green Leafy Vegetables in SouthEast Zone Nigeria. J Food Process Technol 5: 389. doi:10.4172/2157-7110.1000389

35. Handelman GJ (2001) The evolving role of carotenoids in human biochemistry. Nutrition 17: 818-22.

36. Young AJ, Lowe GM (2001) Antioxidant and prooxidant properties of carotenoids. Arch Biochem Biophys 385: 20-27.

37. Booth S, Bressani R, Johns T (1992) Nutrient content of selected indigenous leafy vegetables consumed by the Kekchi people of Alta Verapaz, Guatemala. Journal of Food Composition and Analysis 5: 25-34.

38. Ranhotra GS, Gelroth JA, Leinen SD, Vinas MA, Lorenz KJ (1998) Nutritional profile of some edible plants from México. Journal of Food Composition and Analysis 11: 298-304.

39. Angélica B, María R, Arnaud-Viñas, Gabino AMG, Medina PSS, et al. (2011) The traditional medicinal and food uses of four plants in Oaxaca, Mexico. Journal of Medicinal Plants Research 5: 3404-3411.

40. Adeniran OI, Olajide OO, Igwemmar NC, Orishadipe AT (2013) Phytochemical constituents, antimicrobial and antioxidant potentials of tree spinach [Cnidoscolus aconitifolius (Miller). Journal of Medicinal Plants Research 7: 1317-1322.

41. Adeniran I, Hancox JC, Zhang $\mathrm{H}$ (2013) In silico investigation of the short QT syndrome, using human ventricle models incorporating electromechanical coupling. Front Physiol 4: 166
42. Haddad EH, Berk LS, Kettering JD, Hubbard RW, Peters WR (1999) Dietary intake and biochemical, hematologic, and immune status of vegans compared with nonvegetarians. Am J Clin Nutr 70: 586S-593S.

43. Jimoh FO, Babalola SA, Yakubu MT (2009) Assessment of the antioxidant potential of Cnidoscolus chayamansa. Pharm Biol 47: 903-909.

44. Shibata A, Paganini HA, Ross RK, Henderson BE (1992) Intake of vegetables, fruits, beta-carotene and vitamin $C$ and vitamin supplements and cancer incidence among the elderly: A prospective study. Br J Cancer 66: 673-679.

45. Packer $L$ (1991) Protective role of vitamin $E$ in biological systems. Am J Clin Nutr 53: 1050-1055.

46. Packer L (1997) Oxidants, antioxidant nutrients and the athlete. J Sports Sci 15: $353-363$

47. Emeka EJI, Onyechi O (2009) Some Biochemical, Haematological and Histological Responses to long tern Consumption of Telferiria OccidententalisSupplemented Diets in rats. Pakistan Journal of Nutrition 8: 1199-1203.

48. Nwanna EE, Oboh G (2007) Antioxidant and hepatoprotective properties of polyphenol extracts from Telfairia occidentalis (Fluted Pumpkin) leaves on acetaminophen induced liver damage. Pak J Biol Sci 10: 2682-2687.

49. Halliwel B, Gutteridge JMC (1999) Free radicals in biology and medicine (3rdedn). Oxford; Clarendon press. 